

OPEN

SUBJECT AREAS:

ENTOMOLOGY

INVASIVE SPECIES

ECOLOGICAL EPIDEMIOLOGY

VIRUS-HOST INTERACTIONS

Received

28 March 2013

Accepted

5 July 2013

Published

22 July 2013

Correspondence and requests for materials should be addressed to Y.J.Z. (zhangyoujun@ caas.cn)

* These authors contributed equally to this work.

\section{Virus infection of a weed increases vector attraction to and vector fitness on the} weed

\author{
Gong Chen ${ }^{1,2 *}$, Huipeng Pan ${ }^{2 *}$, Wen $\mathrm{Xie}^{2}$, Shaoli Wang ${ }^{2}$, Qingiun $\mathrm{Wu}^{2}$, Yong Fang ${ }^{2}$, Xiaobin Shi ${ }^{2}$ \\ \& Youjun Zhang ${ }^{2}$
}

${ }^{1}$ College of Plant Protection, Hunan Agricultural University, Changsha, P. R. China, ${ }^{2}$ Department of Plant Protection, Institute of
Vegetables and Flowers, Chinese Academy of Agricultural Sciences, Beijing, P. R. China.

Weeds are important in the ecology of field crops, and when crops are harvested, weeds often become the main hosts for plant viruses and their insect vectors. Few studies, however, have examined the relationships between plant viruses, vectors, and weeds. Here, we investigated how infection of the weed Datura stramonium L. by tomato yellow leaf curl virus (TYLCV) affects the host preference and performance of the TYLCV vector, Bemisia tabaci (Gennadius) $Q$. The results of a choice experiment indicated that $B$. tabaci $Q$ preferentially settled and oviposited on TYLCV-infected plants rather than on healthy plants. In addition, $B$. tabaci $Q$ performed better on TYLCV-infected plants than on healthy plants. These results demonstrate that TYLCV is indirectly mutualistic to $B$. tabaci $Q$. The mutually beneficial interaction between TYLCV and $B$. tabaci $Q$ may help explain the concurrent outbreaks of TYLCV and B. tabaci $Q$ in China.

lant-pathogen-vector systems are characterized by complex direct and indirect interactions ${ }^{1,2}$. The effects of the virus-infected plant on the vectors can be deleterious ${ }^{3}$, neutral ${ }^{4}$, or beneficial ${ }^{1,5}$ depending on the combination of virus, vector, and plant. Although many studies have been conducted on crop-pathogenvector systems, research regarding the interactions between viruses, vectors, and weed is lacking. Weeds, however, are important components of crop ecosystems. When crops are harvested, for example, weeds often become the main host of plant viruses and their insect vectors.

Datura stramonium L. (Solanaceae) is a summer weed that originated in the Americas and has a worldwide distribution ${ }^{6}$. D. stramonium can produce $\geq 100$ seed capsules per plant, and each capsule contains 200-300 seeds ${ }^{7}$. Seeds are dormant at maturity ${ }^{8}$ and may remain viable for 39 years in the soil ${ }^{9}$. With its rapid growth and high requirements for water, light, and nutrients, $D$. stramonium is highly competitive ${ }^{10-12}$. D. stramonium is also a host for many plant viruses, including tomato yellow leaf curl virus (TYLCV) ${ }^{13}$.

TYLCV is a single-stranded DNA (ssDNA) plant virus in the genus Begomovirus, family Geminiviridae. It causes an economically important disease of the Solanaceae in many tropical and subtropical regions worldwide ${ }^{14,15}$. In China, TYLCV has been documented in 11 provinces $^{16}$. This exotic virus was first detected in symptomatic tomato plants in March 2006 in Shanghai, China ${ }^{17}$. Since then, it has spread north to Heilongjiang, Liaoning, Neimenggu, Hebei, Beijing, Shandong, Shanxi, Jiangsu, Zhejiang, and Hubei provinces, where it has caused extensive damage to tomato crops ${ }^{16}$. TYLCV is transmitted by the whitefly Bemisia tabaci (Homoptera: Aleyrodidae) in a circulative and persistent manner ${ }^{13,18,19}$.

Bemisia tabaci (Gennadius) is an important crop pest worldwide. It damages crops by direct feeding and by transmitting plant viruses ${ }^{20}$. The most severe damage results from its transmission of begomoviruses. To date, more than 200 species of begomoviruses are known to be exclusively transmitted by B. tabaci ${ }^{21,22}$. B. tabaci has been regarded as a species complex consisting of many biotypes that are morphologically indistinguishable but that differ in host range, virus transmission, insecticide resistance, or the symbionts that they harbor ${ }^{16,20,23-26}$. The two most invasive and destructive biotypes, B. tabaci biotype B (hereafter referred to as B) and biotype Q (hereafter referred to as Q), are regarded as the Middle East-Minor Asia 1 and the Mediterranean genetic group, respectively ${ }^{27}$.

In China, B. tabaci was first recorded in the late $1940 \mathrm{~s}^{28}$. The crop damage and economic losses caused by this pest, however, did not become serious until the introduction of $B$. tabaci B in the mid- $1990 \mathrm{~s}^{29}$. Since then, B has spread rapidly across the entire country and has caused serious losses to many crops ${ }^{30}$. As a new invasive whitefly, 

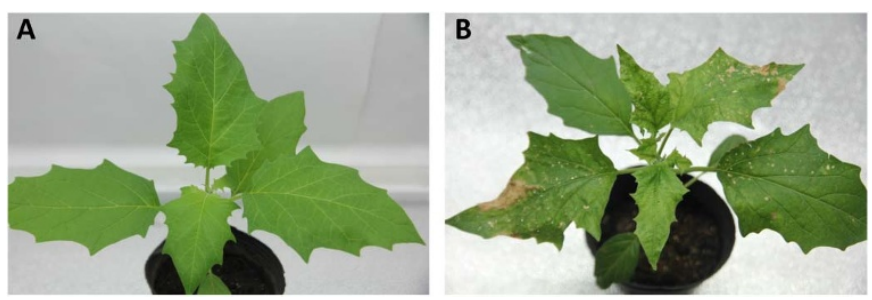

Figure 1 Symptoms of healthy and TYLCV-infected Datura stramonium. Figure (1A) shows healthy D. stramonium plants, Figure (1B) shows TYLCV-infected D. stramonium plants. These photographs were taken by Gong Chen.

Q was first found in Yunnan Province of China in $2003^{30}$. During the past several years, Q has gradually displaced earlier well-established $B$ populations in field and protected crop systems and has become the dominant B. tabaci in most parts of China ${ }^{31,32}$.

The concurrence of the spread of TYLCV with the invasion of $Q$ rather than $B$ suggests a more mutualistic relationship between TYLCV and Q than B. We have recently demonstrated that $\mathrm{Q}$ is a better vector of TYLCV than $\mathrm{B}^{16}$ in that $\mathrm{Q}$ acquires significantly more viral DNA than the $B$ and attains the maximum viral load in a substantially shorter time. Although TYLCV is transmitted horizontally by both whiteflies, transmission frequencies are higher with $\mathrm{Q}$ than $\mathrm{B}^{16}$. We hypothesize that weed hosts are important in the epidemiology of TYLCV. To test this hypothesis, we investigated whether B. tabaci Q prefers to settle and oviposit on TYLCV-infected rather than on healthy $D$. stramonium plants. We also compared the fitness of B. tabaci $\mathrm{Q}$ when feeding on TYLCV-infected vs. healthy $D$. stramonium.

\section{Results}

Symptoms and viral load in TYLCV-infected and healthy D. stramonium. Compared to the healthy D. stramonium plants (Fig. 1A), TYLCV-infected plants exhibited yellow leaf curling and stunting (Fig. 1B). The viral load was significantly higher in the TYLCVinfected plants than in the healthy plants $\left(F_{1,22}=2545.161, d f=\right.$ $22, P<0.0001$, Fig. 2).

Whitefly settling and oviposition preference. More Q adults settled on TYLCV-infected plants than on healthy plants $\left(F_{1,16}=7591.451\right.$,
$P<0.0001$ ) (Fig. 3). Oviposition was greater on TYLCV-infected plants than on healthy plants $\left(F_{1,22}=83.223, P<0.001\right)$ (Fig. 4$)$.

The fitness of Bemisia tabaci $Q$ on TYLCV-infected and healthy $D$. stramonium. Although virus infection of $D$. stramonium plants did not affect whitefly egg to adult development time $\left(F_{1,22}=0.744, P=\right.$ 0.398 ) (Fig. 5A), it did affect other whitefly fitness parameters. TYLCV infection of $D$. stramonium plants increased female body length $\left(F_{1,98}=10.587, P=0.002\right)$ (Fig. $\left.5 \mathrm{~B}\right)$, male body length $\left(F_{1}\right.$, $\left.{ }_{98}=7.005, P=0.009\right)$ (Fig. $5 \mathrm{C}$ ), survival (egg to adult) $\left(F_{1,22}=\right.$ 7.476, $P=0.012)$ (Fig. 5D), longevity $\left(F_{1,58}=32.715, P<0.001\right)$ (Fig. 5E), and fecundity $\left(F_{1,58}=39.435, P<0.001\right)$ (Fig. 5 F).

\section{Discussion}

Virus-vector relationships can range from parasitic to mutualistic, depending on whether the effect of a virus on its vector is deleterious, neutral, or beneficial. Given the concurrent outbreak and spread of TYLCV with the invasion of $Q$ rather than $B$, we tested the hypothesis that the relationship between TYLCV and Q in China is mutualistic.

This hypothesis was supported by the results of the current study. First, TYLCV infection of a host plant (D. stramonium) indirectly improved the overall performance (in terms of survival, fecundity, longevity, and female and male body size) of Q (Fig. 5). Second, $B$. tabaci Q preferred to settle and oviposit on TYLCV-infected plants rather than on healthy plants (Fig. 3 and Fig. 4). Additional evidence of a mutualistic relationship between $B$. tabaci Q and TYLCV was provided by Pan et al. $(2012)^{16}$, who reported that B. tabaci Q transmits TYLCV with high efficiency.

These findings are consistent with previous reports that pathogens and parasites can induce changes in their hosts that influence hostvector interactions ${ }^{33,34}$. Through these studies, we know that vectors of persistently transmitted viruses tend to be attracted to infected host plants and that persistently transmitted viruses tend to improve host plant quality for the vectors and to promote long-term feeding of the vector on the host plant ${ }^{34}$. The status of the vector (viruliferous or not) can also influence its behavior in a way that benefits the virus. In a recent study, we conducted two experiments testing the effect of TYLCV (a persistently transmitted virus) infection of the host (tomato) on vector (B. tabaci B and Q) feeding behavior using an electrical penetration graph (EPG). B. tabaci B and Q both appeared

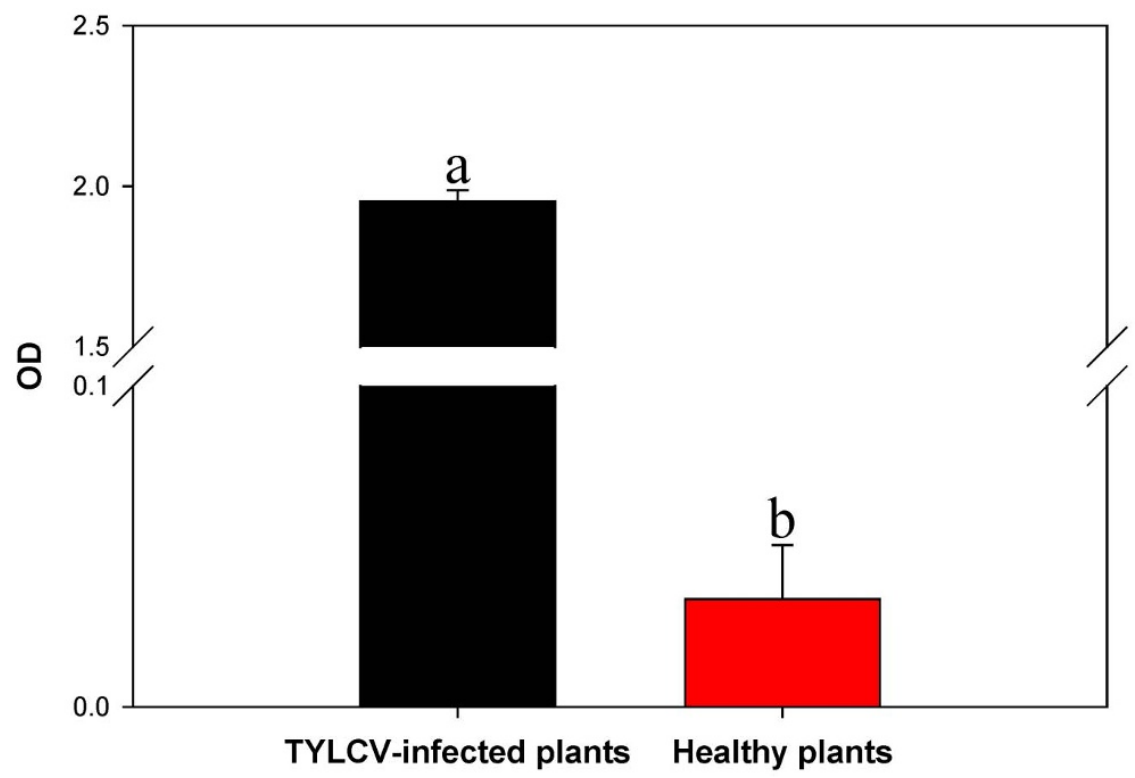

Figure $2 \mid$ Viral load in healthy and TYLCV-infected Datura stramonium. 


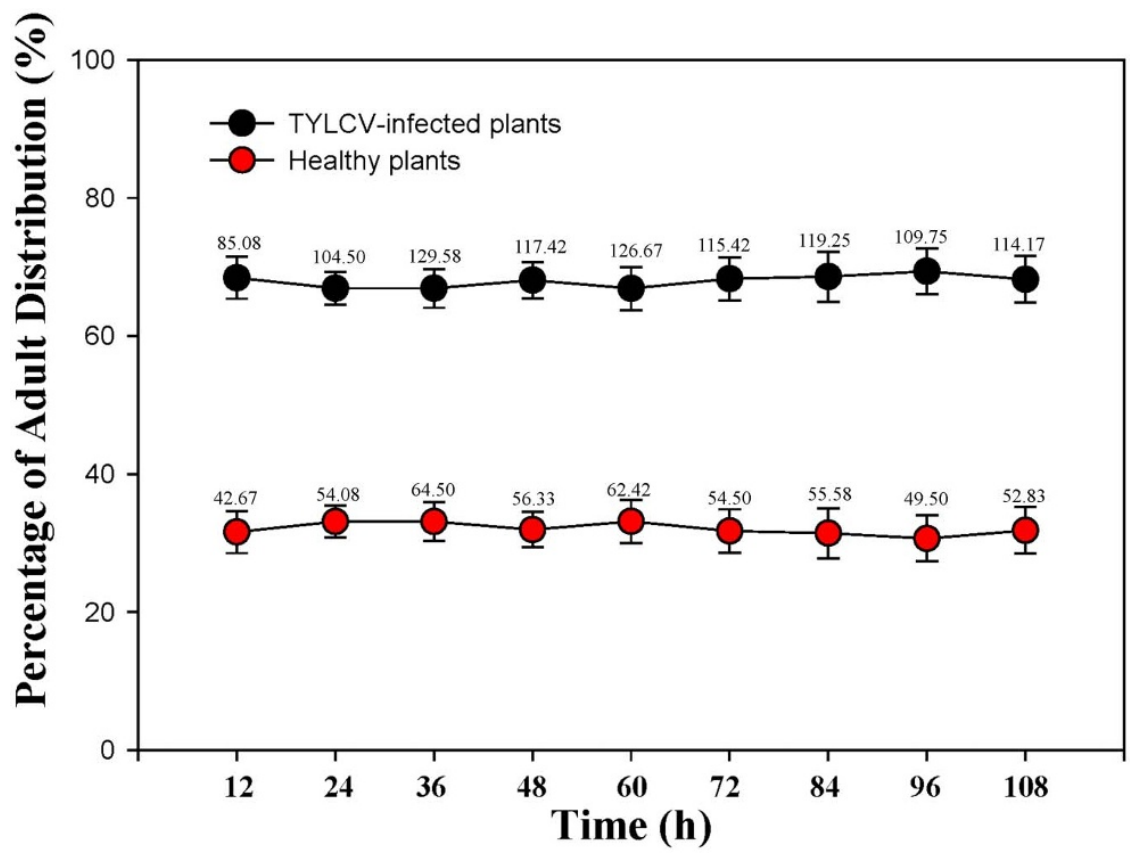

Figure 3 Percentage of $B$. tabaci Q individuals that settled on healthy vs. TYLCV-infected Datura stramonium in a choice test. The real number of adult whiteflies are shown in the figure.

to find TYLCV-infected plants more attractive than healthy plants, probing them more quickly and exhibiting a greater number of feeding bouts; TYLCV infection of host plant did not, however, alter the total time spent feeding. Interestingly, viruliferous whiteflies fed more readily than nonviruliferous whiteflies and spent more time salivating into sieve tube elements. Because vector salivation is essential for viral transmission, this virus-mediated alteration of behavior should directly benefit TYLCV fitness ${ }^{35}$.

In addition, virus infection may alter plant volatiles in ways that might be beneficial or detrimental to the herbivorous vectors of the virus $^{34}$. In a preliminary experiment, the percentage of 1-dodecanol was significantly lower in the volatiles of TYLCV-infected vs. healthy D. stramonium plants, and squalene was only detected in the
TYLCV-infected plants (GC, unpublished data). Further experiments are needed to investigate how virus-induced changes in plant volatiles affect host selection by B. tabaci $\mathrm{Q}$.

That Q whiteflies had greater survival, fecundity, body size, and longevity when feeding on TYLCV-infected D. stramonium than on healthy plants (Fig. 5) demonstrates the occurrence of an indirect mutualism between Q and TYLCV mediated by the host plant. Apparently, TYLCV infection alters the D. stramonium plants, and the resulting changes are beneficial to Q. Our results are consistent with the conclusion that vectors perform better on plants infected with persistently transmitted viruses ${ }^{34}$. Infection by a virus could influence the preference and performance of its herbivorous vectors in several ways. First, virus infection often alters plant morphology,



Figure $4 \mid$ Percentage of eggs (mean \pm SE) laid by B. tabaci $Q$ on healthy vs. TYLCV-infected Datura stramonium in a choice test. The real number of eggs is shown in the figure. Different letters indicate a significant difference $(P<0.05)$. 

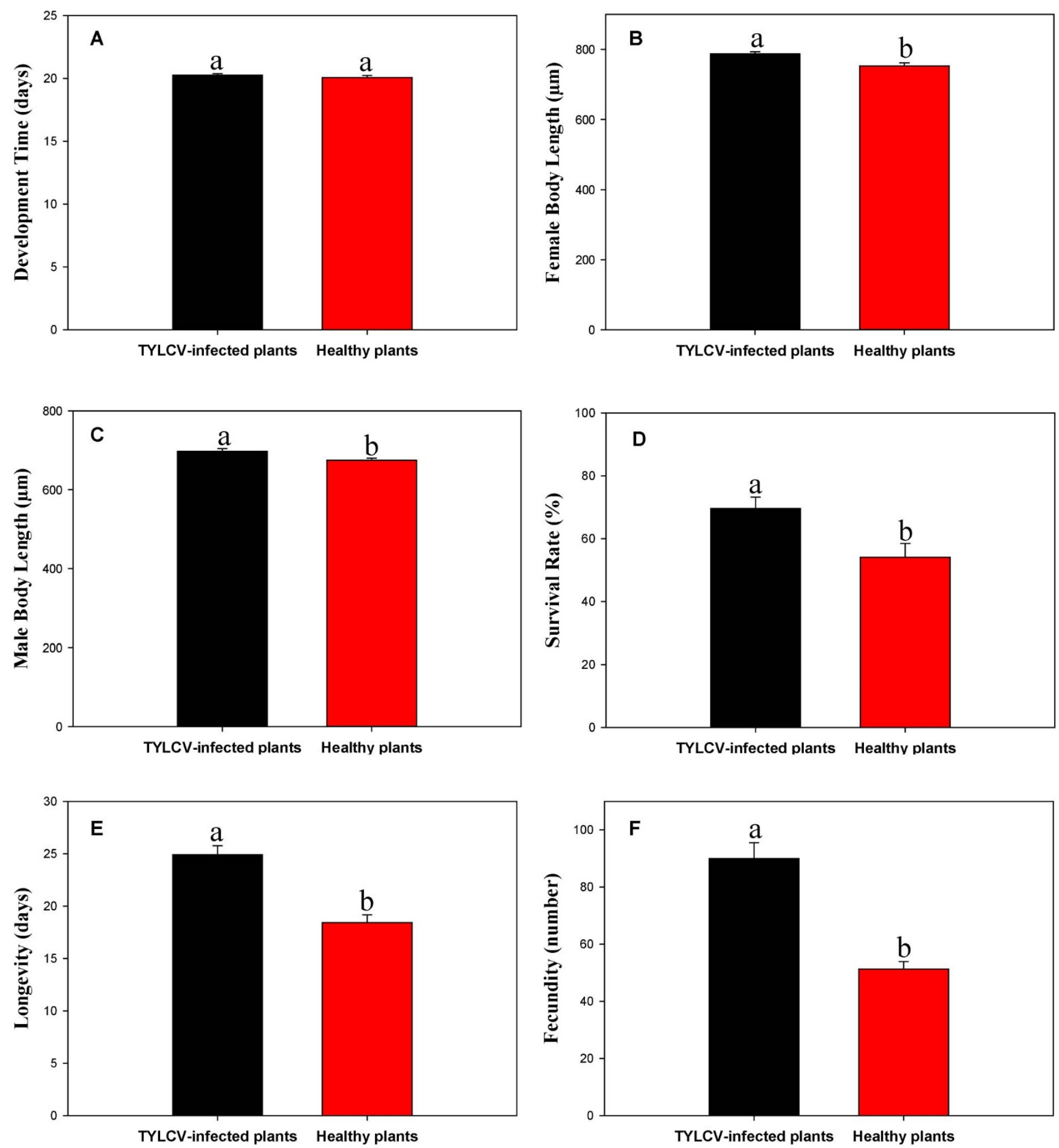

Figure $5 \mid$ Life history traits of B. tabaci Q on healthy vs. TYLCV-infected Datura stramonium. (A) Development time (from egg to adult) based on 12 replicates. (B) Female body length (from head to tip of abdomen) based on 50 replicates. (C) Male body length (from head to tip of abdomen) based on 50 replicates. (D) Survival rate (the total number of emerged adult whiteflies/the total number of eggs) based on 12 replicates. (E) Longevity (from newly emerged adult until its death) based on 30 replicates. (F) Fecundity (the total number of eggs laid by each female) based on 30 replicates. Values are means \pm SE. Within each panel, different letters indicate significant differences between treatments $(P<0.05)$.

and these changes could be beneficial or detrimental to herbivorous vectors. Second, virus infection can change the composition and percentage of free amino acids in the phloem or in other ways change the nutritional composition of the plant tissue $e^{2,36}$ and thereby change the fitness of herbivorous vectors ${ }^{36,37}$. Finally, viruses can benefit a herbivorous vector by suppressing plant defenses against herbivores $^{1}$. Additional experiments are required to determine whether these mechanisms or other mechanisms explain why TYLCV infection generally improves the fitness of B. tabaci Q on D. stramonium.

Our previous research showed that TYLCV infection can improve the performance of its vector B. tabaci $Q$ on tomato ${ }^{38}$. Here, we have shown that TYLCV infection improves vector attraction to and fitness on its weed host D. stramonium. Overall, the results suggest that the indirect and direct interactions between TYLCV and B. tabaci Q 
are mutually beneficial and may help explain the concurrent outbreaks and spread of TYLCV and B. tabaci Q in China.

\section{Methods}

Bemisia tabaci laboratory population. Since its collection in Beijing, China, in $2009^{16}$, the B. tabaci Q population used in this study has been maintained on poinsettia (Euphorbia pulcherrima Wild. ex. Klotz.) in isolated whitefly-proof screen cages with natural lighting and controlled temperature $\left(26 \pm 2{ }^{\circ} \mathrm{C}\right)$ in a glasshouse. The purity of the population has been monitored by determining the cleavage amplified polymorphic sequence (CAPS) and mitochondrial cytochrome oxidase I genes $(m t C O I)$ for 15 adults per generation ${ }^{31}$.

Plant cultures and TYLCV inoculation. Datura stramonium L. was grown in a potting mix (a mixture of peat moss, vermiculite, organic fertilizer, and perlite in a $10: 10: 10: 1$ ratio by volume) in 1.5 -L pots (one plant/pot) under natural light and with controlled temperature $\left(26 \pm 2{ }^{\circ} \mathrm{C}\right)$ in a glasshouse. TYLCV-infected $D$. stramonium plants were obtained by Agrobacterium tumefaciens-mediated inoculation using a cloned TYLCV genome (GenBank accession ID: AM282874), which was originally isolated from tomato plants in Shanghai, China ${ }^{17}$. Inoculation was carried out at the 3 true-leaf stage. Viral infection of test plants was confirmed by the development of characteristic leaf curl symptoms and was further validated by molecular analysis as described previously ${ }^{16}$. When these plants grew to the 7 true-leaf stage, they were used in the experiments.

TAS-ELISA. When D. stramonium plants that were or were not inoculated with TYLCV grew to the 7 true-leaf stage, they were tested for TYLCV with a triple antibody sandwich enzyme-linked immunosorbent assay (TAS-ELISA). Leaf samples (the third leaf from the top; $0.1 \mathrm{~g}$ per sample) were ground in $1 \mathrm{ml}$ of extraction buffer. Each of the two treatments was represented by 12 replicates. A kit supplied by Adgen Phytodiagnotics (Neogen Europe (Ayr), Ltd) was used, and the manufacturer's protocol was followed. Absorbance was read with a fluorescence microplate reader at the wavelength of $405 \mathrm{~nm}$ (SpectraMax M2e, Molecular Devices). The samples were considered positive for TYLCV when the mean optical density (OD) values at $405 \mathrm{~nm}$ were over three times that of the healthy controls.

Whitefly settling and oviposition preference. Experiments concerning whitefly settling and oviposition preference were performed as described by Omondi et al. $(2005)^{39}$. Briefly, individual plants of healthy and TYLCV-infected D. stramonium of approximately the same size were arranged in opposite corners of a screen cage $(60 \times$ $40 \times 80 \mathrm{~cm}$; two plants per cage). About 300 adult whiteflies were collected between 07:00-08:00 am and released near the center-bottom of each cage. This was accomplished by placing the aspirator sampling bottle containing whiteflies in a clear plastic tumbler located in the center of the cage. Whiteflies moved to the open top and flew out of the sampling bottle. The number of whiteflies on each plant was determined after $12,24,36,48,60,72,84,96$, and $108 \mathrm{~h}$. To avoid disturbing whiteflies and causing them to relocate during counting, whiteflies were counted under dim light just before 06:00 am and just after 18:00 pm. After 108 h, all leaves from each plant were removed, and the whitefly eggs on each leaf were counted with the aid of a stereomicroscope (Leica, M205C). At the beginning, there were a total of 12 cages with insects and plants drawn from the same pool, and the replicate cages were arranged in parallel with each side having six replicate cages (healthy vs. virusinfected plants) under natural lighting and ambient temperature $\left(26 \pm 2{ }^{\circ} \mathrm{C}\right)$ in a glasshouse.

Life history traits of whiteflies on healthy and TYLCV-infected plants. Adults of $B$. tabaci $\mathrm{Q}$ from poinsettia were transferred to and reared on healthy or TYLCVinfected D. stramonium plants. For each replicate (there were 12 replicates for each of the two treatments), 20 newly emerged females were collected from poinsettia and enclosed in one clip-cage, with one clip-cage per plant. The 20 females in each cage were allowed to oviposit on the D. stramonium leaf for $24 \mathrm{~h}$. The adults were then removed. The leaves were then examined with a stereomicroscope (Leica, M205C), and the eggs were counted. Leaves bearing eggs were marked with a marker pen. From the 15th day onwards, the newly emerged adults were collected and recorded twice daily (at 9:00 and 15:00) until all the pupae had developed to adults. The total number of emerged adult whiteflies in each replicate was calculated at the end of the experiment. The length of each newly emerged adult was measured with a stereomicroscope (Leica, M205C) after the adult had been stored at $-20^{\circ} \mathrm{C}$ for $15 \mathrm{~min}$. From these data, development time (from egg to adult), survival (the total number of emerged adult whiteflies/the total number of eggs*100), and the female and male body lengths (from head to tip of abdomen) were calculated.

Bemisia tabaci Q fecundity (the total number of eggs per female) and longevity (from newly emerged adult until its death) on healthy and TYLCV-infected $D$. stramonium plants were also determined. One newly emerged female from a healthy poinsettia plant was collected and transferred to a clip-cage attached to a leaf of a healthy or TYLCV-infected D. stramonium plant. There were 30 replicate clip-cages for each of the two treatments. Eight plants were used for each of the two treatments; seven plants enclosed with four clip-cages; one plant enclosed with two clip-cages. Every 7 days, the eggs on the leaves were counted with a stereomicroscope (Leica, $\mathrm{M} 205 \mathrm{C}$ ), and each adult female was transferred to new leaf until she died. The survival of the female in each replicate was recorded every day to calculate its longevity.
Data analysis. Repeated-measures ANOVAs were used to compare the whitefly settling preference on healthy and TYLCV-infected D. stramonium plants. One-way ANOVAs were used to compare whitefly oviposition preference and life history parameters on the healthy and TYLCV-infected D. stramonium plants, and to compare the viral load in the healthy and TYLCV-infected $D$. stramonium plants. SPSS version 19.0 (SPSS Inc., Chicago, IL, USA) was used for all statistical analyses. All proportional data were arcsine square root transformed before analyses.

1. Belliure, B., Janssen, A., Maris, P. C., Peters, D. \& Sabelis, M. W. Herbivore arthropods benefit from vectoring plant viruses. Ecol. Lett. 8, 70-79 (2005).

2. Stout, M. J., Thaler, J. S. \& Thomma, B. P. H. J. Plant-mediated interactions between pathogenic microorganisms and herbivorous arthropods. Annu. Rev. Entomol. 51, 663-689 (2006).

3. Rubinstein, G. \& Czosnke, H. Long-term association of tomato yellow leaf curl virus with its whitefly vector Bemisia tabaci: effect on the insect transmission capacity, longevity and fecundity. J. Gen. Virol. 78, 2683-2689 (1997).

4. Matsuura, S. \& Hoshino, S. Effect of tomato yellow leaf curl disease on reproduction of Bemisia tabaci Q biotype (Hemiptera: Aleyrodidae) on tomato plants. Appl. Entomol. Zool. 44, 143-148 (2009).

5. Maris, P. C., Joosten, N. N., Goldbach, R. W. \& Peters, D. Tomato spotted wilt virus infection improves host suitability for its vector Frankliniella occidentalis. Phytopathology 94, 706-711 (2004).

6. Holm, L., Doll, J., Holm, E., Pancho, J. \& Herberger, J. in World Weeds: Natural Histories and Distribution. (John Wiley, New York 1997).

7. Scott, G. H., Askew, S. D., Wilcut, J. W. \& Brownie, C. Datura stramonium interference and seed rain in Gossypium hirsutum. Weed Sci. 48, 613-617 (2000).

8. Reisman, B. O., Kigel, J. \& Rubin, B. Short soaking in water inhibits germination of Datura ferox L. and Datura stramonium L. seeds. Weed Res. 29, 357-363 (1989).

9. Weaver, S. E. \& Warwick, S. I. The biology of Canadian weeds. 64. Datura stramonium L. Can. J. Plant Sci. 64, 979-991 (1984).

10. Cavero, J., Zaragoza, C., Suso, M. L. \& Pardo, A. Competition between maize and Datura stramonium in an irrigated field under semi-arid conditions. Weed Res. 39, 225-240 (1999)

11. Stoller, E. W. \& Woolley, J. T. Competition for light by broadleaf weeds in soybean (Glycine max). Weed Sci. 33, 199-200 (1985).

12. Wesley Jr, R. A., Shaw, D. R. \& Barrentine, W. L. Incorporation depths of imazaquin, metribuzin, and chlorimuron for common cocklebur (Xanthium strumarium) control in soybeans (Glycine max). Weed Sci. 37, 596-599 (1989).

13. Cohen, S. \&Nitzany, F. E. Transmission and host range of the tomato yellow leaf curl virus. Phytopathology 56, 1127-1131 (1966).

14. Boulton, M. Geminiviruses: major threats to world agriculture. Ann. Appl. Biol. 142, 143-144 (2003).

15. Varma, A. \& Malathi, V. G. Emerging geminivirus problems: A serious threat to crop production. Ann. Appl. Biol. 142, 145-164 (2003).

16. Pan, H. P. et al. Rapid spread of Tomato yellow leaf curl virus in China is aided differentially by two invasive whiteflies. PLoS One 7, e34817 (2012).

17. Wu, J. B., Dai, F. M. \& Zhou, X. P. First report of Tomato yellow leaf curl virus in China. Ann. Appl. Biol. 155, 439-448 (2006).

18. Mehta, P., Wyman, J. A., Nakhla, M. K. \& Maxwell, D. P. Transmission of tomato yellow leaf curl geminivirus by Bemisia tabaci (Homoptera: Aleyrodidae). J. Econ. Entomol. 87, 1291-1297 (1994).

19. Caciagli, P., Bosco, D. \& Al-Bitar, L. Relationships of the Sardinian isolate of tomato yellow leaf curl geminivirus with its whitefly vector Bemisia tabaci Gen. Eur J. Plant Pathol. 101, 163-170 (1995).

20. Brown, J. K., Frohlich, D. R. \& Rosell, R. C. The sweetpotato or silverleaf whiteflies: biotypes of Bemisia tabaci or a species complex? Annu. Rev. Entomol. 40, 511-534 (1995).

21. Hogenhout, S. A., Ammar, E. D., Whitfield, A. E. \& Redinbaugh, M. G. Insect vector interactions with persistently transmitted viruses. Annu. Rev. Phytopathol. 46, 327-359 (2008).

22. Nawaz-ul-Rehman, M. S. \& Fauquet, C. M. Evolution of geminiviruses and their satellites. FEBS Lett. 583, 1825-1832 (2009).

23. Perring, T. M. The Bemisia tabaci species complex. Crop Prot. 20, 725-737 (2001).

24. Jones, D. R. Plant viruses transmitted by whiteflies. Eur. J. Plant Pathol. 109, 195-219 (2003).

25. Pan, H. P. et al. Factors affecting population dynamics of maternally transmitted endosymbionts in Bemisia tabaci. PLoS ONE 7, e30760 (2012).

26. Liu, B. M. et al. Difference in feeding behaviors of two invasive whiteflies on host plants with different suitability: Implication for competitive displacement. Int. J. Biol. Sci. 8, 697-706 (2012).

27. De Barro, P. J., Liu, S. S., Boykin, L. M. \& Dinsdale, A. B. Bemisia tabaci: a statement of species status. Annu. Rev. Entomol. 56, 1-19 (2011).

28. Zhou, Y. The list of whiteflies in China. China Entomol. 3, 1-18 (1949).

29. Luo, C. et al. The use of mitochondrial cytochrome oxidase mtCOI gene sequences for the identification of biotypes of Bemisia tabaci (Gennadius) in China. Acta. Entomol. Sin. 45, 759-763 (2002).

30. Chu, D. et al. The introduction of the exotic Q biotype of Bemisia tabaci from the Mediterranean region into China on ornamental crops. Fla. Entomol. 89, 168-174 (2006). 
31. Chu, D., Wan, F. H., Zhang, Y. J. \& Brown, J. K. Change in the biotype composition of Bemisia tabaci in Shandong Province of China from 2005 to 2008. Environ. Entomol. 39, 1028-1036 (2010).

32. Pan, H. P. et al. Further spread of and domination by Bemisia tabaci biotype Q on field crops in China. J. Econ. Entomol. 104, 978-985 (2011).

33. Ingwell, L. L., Eigenbrode, S. D. \& Bosque-Pérez, N. A. Plant viruses alter insect behavior to enhance their spread. Sci. Rep. 2, 578 (2012).

34. Mauck, K., Bosque-Pérez, N. A., Eigenbrode, S. D., De Moraes, C. M. \& Mescher, M. C. Transmission mechanisms shape pathogen effects on host-vector interactions: evidence from plant viruses. Funct. Ecol. 26, 1162-1175 (2012).

35. Liu, B. M. et al. Multiple forms of vector manipulation by a plant-infecting virus: Bemisia tabaci and tomato yellow curl leaf virus. J. Virol. 87, 4929-4937 (2013)

36. Mauck, K. E., De Moraes, C. M. \& Mescher, M. C. Deceptive chemical signals induced by a plant virus attract insect vectors to inferior hosts. P. Natl. Acad. Sci. U. S. A. 107, 3600-3605 (2010).

37. Awmack, C. S. \& Leather, S. R. Host plant quality and fecundity in herbivorous insects. Annu. Rev. Entomol. 47, 817-844 (2002).

38. Pan, H. P. et al. Differential effects of an exotic plant virus on its two closely related vectors. Sci. Rep. (in press) (2013).

39. Omondi, A. B., Obeng-Ofori, D., Kyerematen, R. A. \& Danquah, E. Y. Host preference and suitability of some selected crops for two biotypes of Bemisia tabaci in Ghana. Entomol. Exp. Appl. 115, 393-400 (2005).

\section{Acknowledgements}

This research was supported by the National Science Fund for Distinguished Young Scholars (31025020), the Beijing Natural Science Foundation (6131002), the 973 Program (2013CB127602), and the Beijing Key Laboratory for Pest Control and Sustainable

Cultivation of Vegetables. The granting agencies had no role in study design, data collection and analysis, decision to publish, or preparation of the manuscript.

\section{Author contributions}

Y.J.Z., G.C., H.P.P. designed the experiment. G.C., F.Y., X.B.S. performed the experiment. W.X., S.L.W., Q.J.W. contributed reagents/materials. G.C., H.P.P., Y.J.Z. wrote the paper.

\section{Additional information}

Competing financial interests: The authors declare no competing financial interests.

How to cite this article: Chen, G. et al. Virus infection of a weed increases vector attraction to and vector fitness on the weed. Sci. Rep. 3, 2253; DOI:10.1038/srep02253 (2013).

(c) (i) $\Theta$ This work is licensed under a Creative Commons Attribution-

NonCommercial-NoDerivs 3.0 Unported license. To view a copy of this license, visit http://creativecommons.org/licenses/by-nc-nd/3.0 